\section{In the choice between health and money, health comes first: an analysis of happiness among rural Chilean elderly}

\author{
Entre la salud y el dinero, la salud es lo primero: \\ análisis con ancianos chilenos que viven en \\ áreas rurales
}

Entre saúde e dinheiro, saúde é o primeiro: análise dos chilenos idosos que vivem em áreas rurais
German Lobos 1

Maria del Carmen Lapo 2

Berta Schnettler 3

\begin{abstract}
We studied the relationship between happiness and individual socio-demographic context and health and dietary variables by interviewing 389 elderly individuals (age 60-90 years) living in rural areas in the Maule Region of Central Chile. The Lyubomirsky \& Lepper (1999) subjective happiness scale was used. Ordinal logistic regression models were estimated. The discrete dependent variable was level of happiness. The following variables were significantly associated with happiness: (1) individual socio-demographic variables like age and satisfaction with the economic situation; (2) health variables like independence in activities of daily living, common activities, and self-rated health; and (3) dietary variables such as life satisfaction related to food and the frequency with which the elders shared dinner with others. The study results suggest more efficient efforts at healthy eating for the elderly in rural areas.
\end{abstract}

Happiness; Rural Areas; Health Bevahior; Aged

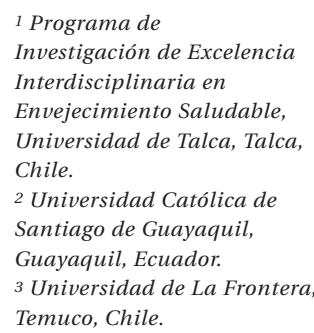

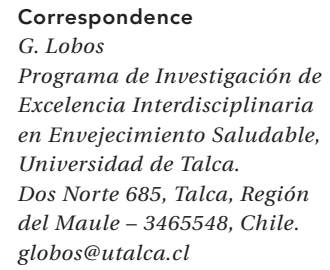




\section{Introduction}

Why are economists interested in studying happiness? One important reason is that studies on happiness help to better analyze the net impact of economic policy ${ }^{1}$. In this sense, the design of public policy must be the result of the cause and effect logic so that the design of the intervention acts on the variables, or causes, that are affecting happiness. Why study happiness among elderly adults? Because globally the trend towards increasingly aging populations is irreversible, and in Chile an increased intensity and speed of change of the demographic profile has been observed for at least three decades. In fact it is expected that by 2050 more than a quarter of the Chilean population will be over 65 years of age. This phenomenon is leading to the modification of conventional ways of looking at seniors and reassessing how to confront this process in terms of the design and implementation of public policies and social intervention programs. As the population rapidly ages and life expectancy increases, the focus lies on finding ways to improve seniors' quality of life. People do not merely wish to survive, but live productively and happily despite the limitations of any chronic age-related conditions 2 . It is therefore important to implement public policies so that older adults can contribute to the social fabric, be happier and achieve greater life satisfaction. Happiness and life satisfaction are subjective measurements of subjective well-being. The concepts of life satisfaction and happiness are interrelated but are not exactly the same 3 ; the former is seen more as the outcome of an evaluation process, while the latter as an outcome of positive experiences 4,5 . Happiness can be beneficial in numerous ways; it has positive implications for society as well as individuals, suggesting that the promotion of happiness is a wise investment in social and public health 6 . The literature reports various studies that have used the Subjective Happiness Scale 7 to measure subjective happiness $2,8,9,10$. Some recent studies relate to older adults. For example, Angner et al. 9 reported a mean happiness score of 5.67 ( $\mathrm{SD}=1.36$ ) on a 7-point scale based on a sample of 383 older adults, patients in a primary care medical center in Alabama, United States. In a large and representative sample of the Hong Kong population, Nan et al. 2 obtained a mean happiness score of $5.09(\mathrm{SD}=1.18)$ on a 7 -point scale for the $65+$ age group. There is widespread international evidence of seniors' happiness using other measurement scales 11,12,13,14,15,16,17,18.

Some studies show that happy individuals are successful across multiple life domains including marriage, friendship, income, work per- formance, and health 10,19 , and more specifically several authors have established a relationship between happiness and income 12,20, education 21,22 , family and friends 23,24 , marital status $13,14,20$, number of children 11,14 , perceived physical and mental health 10,25,26, and capital and social support 13 .

Hsieh 12 examined the relationship between money and happiness across age groups of American adults and concluded that income has a significant positive association with happiness among young and middle-age adults; however, this was not the case for older adults. For China's elderly population Chyi \& Mao 11 found that living with their children has a negative effect on the elderlies' reported level of happiness, but living with grandchildren has a positive effect on happiness. Selim 14 investigated life satisfaction and happiness in Turkey, and some of the results are similar to typical findings in happiness and life satisfaction studies, such as a negative age effect, positive influences of income and health, and a negative effect of unemployment. Additionally, married people are found to have the highest degree of happiness and the effect of the number of children on happiness has been shown to be negative. Education has an insignificant effect on happiness at all levels and, what is more, being male has a significantly negative direct effect on happiness and life satisfaction.

Based on data provided by 180 seniors living in West Virginia, a rural state in Northern Appalachia (United States), Patrick et al. 27 suggested that only emotional support from family and emotional support from friends emerged as significant. According to the authors, age, gender, marital status and education were not significant when explaining the level of well-being. For a sample size of 1,533 Chinese older adults, Chyi \& Mao 11 found that, in contrast to living with a grandchild, living with one's child has a negative effect on happiness. With a sample size of 282 participants, of which the average age at the time of interview was 61 years (range: 49-99), Angner et al. 9 concluded that health is one of the most influential predictors of happiness, and that the association between health and happiness depends greatly on the manner in which health status is measured, and that the degree to which disease disrupts daily functioning is inversely associated with happiness. Gray et al. 3 examined the level of happiness of the Thai elderly population and its relationship to various external and internal factors. According to multiple regression analyses, external factors including economic hardship (such as debt-paying ability), living arrangements (such as living alone), (very good) functional ability, perceived social environment, 
and consumerism (measured as a number of household possessions) significantly influence the level of happiness. The strongest predictor of happiness is, however, the internal factor - that is, a feeling of relative poverty compared to one's neighbors. The authors found that age and gender were not statistically significant.

Based on a household survey in rural areas of the four provinces of Pakistan, Shams 15 found that happiness is significantly affected by gender (women are less likely to be happy), years of education, number of children living in the household, household income, health index, employment status and regional background of the household. Shams' results seem to support the idea of an inverted U-shaped relationship between age and happiness with a theoretical turning point of 65.5 years of age 15 . Portela \& Neira 13 analyzed the determinants of happiness in Spain with special attention to the social capital measured in three dimensions: trust, networks and social norms. The likelihood of being happy is greater if the person is married, in good or very good health, with an acceptable or high subjective income level, and with higher education, regardless of the person's gender. Theurer \& Wister 16 found positive and robust associations with social capital and the two measures of wellbeing (i.e. happiness and life satisfaction) among older Canadians.

Food consumption contributes to hedonic well-being. According to Bisogni et al. 28 choosing food is a process that involves psychological, social, cultural, economic, and biological factors. Hausman 29 has proposed a duality for understanding food consumption: food as both a utilitarian product for support of the body and as a hedonic product for support and social construction of the soul. According to Kniazeva \& Venkatesh 30 food is prepared with the expectation of being shared and enjoyed in the company of family or friends. Hargreaves et al. 31 highlights the emotional dimension of food associated with celebrations and social interaction. Other investigations have also demonstrated that eating is an important source of happiness 32,33,34. Schnettler et al. 35 concluded that satisfaction with food is associated with hedonic reasons linked to enjoyment and to the symbolic association of certain foods with the collective enjoyment of social occasions rather than nutrition or health.

According to results from previous studies, we expected to confirm the relationship between older adults' happiness and health-related variables $3,9,10,13,14,15,20,34$. In addition, considering the relationship between social interaction and food 31, and happiness and food 32,33, this study intends to demonstrate that the level of satisfaction with food-related life and having company during meals are related to happiness. Given that social policy needs objective indicators 36 we expect to provide perceived indicators for policy makers to improve their perceptions and understanding of the lives of Chilean seniors. In this research the relationship between happiness and individual sociodemographic, health-related and food-related variables was explored using a cross-sectional survey of 389 Chilean rural older adults. Four research questions were addressed:

1. How is the relationship between expenditure on food consumption and happiness by gender? 2. Which individual sociodemographic variables explain happiness among elderly, rural Chileans?

3. What are the health-related variables that contribute significantly to explaining happiness? 4. What are the food-related variables that contribute significantly to explaining happiness?

\section{Data and methods}

\section{Design, sampling and participants}

A stratified random sampling was conducted with proportional affixation comprised of 389 older adults (age range: 60-90) from 30 communes of the Maule Region of central Chile. The inclusion criterion was to be registered in a Seniors' Center and living in rural areas. This is justified because $33 \%$ of the population of the Maule Region is rural, making it Chile's most rural region. The sample included both male and female participants. Work was done on the complete sample because Lobos et al. 10 studied the gender differences and happiness in Chilean rural older adults. Finally, the sample included seniors belonging to different socioeconomic levels. The expected maximum absolute error level of the questionnaire results was $\pm 5 \%$ for a confidence level of $95 \%$ and maximum variance. The participants did not receive any incentive to participate in this study.

\section{Procedure}

The Ethics Committee of the Universidad de Talca approved the study protocol. Participants were recruited through Seniors' Centers to answer the questionnaire either in the Center or in their residence. The participants signed informed consent statements before responding. The consent statements explained the strictly confidential treatment of the information obtained. The questionnaire was personally administered by trained interviewers in May 2013 and 
January 2104. Application of the questionnaire lasted 20-25 minutes.

\section{Measures}

The questionnaire applied included the following scales:

Subjective Happiness Scale (SHS): developed by Lyubomirsky \& Lepper 7, this consists of four items that must be answered on a Likert scale of 1-7 points. Scores are totaled for the four items, and range from 4 to 28 . The scale is calculated based on the average score of all items, where higher scores reflect greater happiness. This study used the Spanish version of the SHS, which has previously shown good levels of internal consistency in studies with Chilean population $10,18,23$. In this study, the SHS presented good internal consistency (Cronbach's $\alpha$ of 0.74). Applying the technique proposed by Vera-Villarroel et al. 37 , the happiness variable was converted into an ordinal trinomial variable, grouping cases with scores below the 25th percentile and cases above the 75th percentile. Cases with scores below 4.75 (25th percentile) were classified as 1 (not happy), cases with average scores above 6 (75th percentile) were classified as 2 (happy) and cases with average scores between both percentiles were classified as 3 (very happy). Thus, happiness was used as an independent variable in the estimations.

Satisfaction with Food-related Life Scale (SWFL): as proposed and tested by Grunert et al. 38 , this consists of five items grouped into a single dimension. Respondents must indicate their degree of agreement with the statements using a 6-point Likert scale (1: strongly disagree, 6: strongly agree). This scale has shown good internal consistency (Cronbach's $\alpha$ between 0.79 and 0.88 ) in studies conducted in European countries 38 and Chile ${ }^{35,39}$. In the present study, Cronbach's $\alpha$ was 0.85 .

Health-Related Quality of Life Index (HRQoL): as developed by Hennessy et al. 40 , this consists of four items that explore the self-perception of health, recent physical health, recent mental health, and recent limitations on activity. Toet et al. 41 validated the Dutch version of the HQRoL reporting good reliability (Cronbach's $\alpha$ of three of the four items was 0.77 ). This study used the Spanish-language version, which showed good internal consistency (Cronbach's $\alpha$ of 0.78 ) in a previous study in Chile ${ }^{42}$. In the present study, Cronbach's $\alpha$ of three (items measuring recent physical health, recent mental health, and recent limitations on activity) of the four items was 0.86 .

Index of Independence in Activities of Daily Living (known as the Katz ADL): as developed by Katz et al. 43, this assesses six basic functions. The participants were asked to rate their ability to perform these basic functions on a six-item scale, a four-point Likert-type from 1 to 4 . A cumulative score for each respondent was obtained by totaling the scores of the six items. The functional limitation score ranged from 6 to 24, with a higher score indicating fewer functional limitations. In the present study, Cronbach's $\alpha$ was 0.91 .

The "satisfaction with economic situation" (SWES) was used as a proxy for income. The interviewee had to rate their satisfaction with their economic situation scoring from 1 to 6 . SWES was recoded as 1 (dissatisfied), 2 (slightly satisfied), 3 (somewhat satisfied) and 4 (extremely satisfied). To assess the socioeconomic level, this study adopted the criterion proposed by Adimark 44 .

Other measures included were age (years), gender, living circumstances, number of children living at home, education attainment in eight levels, and quantity of domestic household goods (QGoods). Food household expenditure and per capita food expenditure of an individual in a household, which divides household expenditure by the size of the household 12,45 were also considered. Questions regarding the frequency with which the respondent eats accompanied by other people in the household, as "frequency of dinner in company", were also included. The variables used in the analysis are itemized with their respective categories in Table 1.

\section{The models}

Logistic ordinal regression models were estimated. The dependent variable is level of happiness ( 1 = not happy, 2 = happy, 3 = very happy), which is discrete. The independent variables include the components of happiness. In the first step (Model 1), sociodemographic variables included: SWES, age, gender, living circumstances, living with or without children, level of education, QGoods, and socioeconomic level. In the second step (Model 2), the health-related variables were added to the model, and in the final step (Model 3), the food-related variables were added. In these regression models the parameters were estimated by the maximum likelihood method, which is associated with random variable density functions. The construction process of the happiness model began with the equation 46 :

$y_{i}^{*}=\beta_{0}+\Sigma k_{j=1} \beta_{j} x_{i j}+\varepsilon_{i}$

Where $y_{i}^{*}$ is an unobservable variable, $\beta_{j}$ is a parameters vector, $x_{i}$ is an independent variables vector, $\varepsilon_{i}$ is an independent and identically distributed error term. Thus, it is assumed that 
Table 1

Definitions and sample characteristics (elderly Chileans living in rural areas) $(N=389)$.

\begin{tabular}{|c|c|c|c|}
\hline Variable & Definition & Mean or \% & SD \\
\hline Age & In years (range: 60-90) & 71.4 & 6.5 \\
\hline Male & Dummy variable $(1=$ male, $0=$ female $)$ & 37.4 & \\
\hline Living alone & Dummy variable $(1=$ yes, $0=$ no $)$ & 38.2 & \\
\hline Children & Number (range: 0-6) & 0.5 & 0.9 \\
\hline Education & Education attainment in 8 levels ( $1=$ no formal education, $\ldots, 8=$ college or more) & 2.9 & 1.5 \\
\hline QGoods & Number (range: $0-10)$ & 6.2 & 1.9 \\
\hline Food household expenditure * & 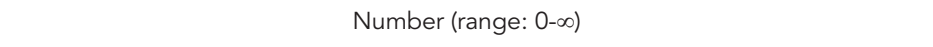 & 168.1 & 89.8 \\
\hline Per capita food expenditure ** & 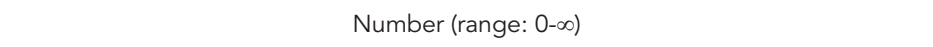 & 74.1 & 47.6 \\
\hline \multicolumn{4}{|l|}{ Socioeconomic level } \\
\hline $1=A B C 1$ & $1=$ high and upper middle & 2.1 & \\
\hline $2=C 2$ & $2=$ middle-middle & 9.0 & \\
\hline $3=C 3$ & $3=$ middle-low & 22.6 & \\
\hline $4=D$ & $4=$ low & 56.6 & \\
\hline $5=\mathrm{E}$ & $5=$ very low & 9.8 & \\
\hline Unhealthy days index & Number (range: 0-30) & 6.1 & 10.2 \\
\hline Happiness & Number (range: $1-7$ ) & 5.3 & 1.0 \\
\hline Happiness & SHS attainment in 3 levels & & \\
\hline 1 = not happy & & 31.9 & \\
\hline 2 = happy & & 37.0 & \\
\hline $3=$ very happy & & 31.1 & \\
\hline Age-squared & In years (range: $3,600-8,100$ ) & $5,132.6$ & 946.2 \\
\hline SWES & Attainment in 6 levels & & \\
\hline 1 = dissatisfied & $1=$ extremely, 2 = somewhat, and $3=$ slightly dissatisfied & 18.6 & \\
\hline 2 = slightly satisfied & $4=$ slightly satisfied & 34.6 & \\
\hline $3=$ somewhat satisfied & $5=$ somewhat satisfied & 38.0 & \\
\hline $4=$ extremely satisfied & $6=$ extremely satisfied & 8.8 & \\
\hline Katz ADL & Number (range: 6-24) & 17.3 & 2.1 \\
\hline Common activities & Number (range: 0-30) & 2.8 & 7.2 \\
\hline Health & Perceived health attainment in 5 levels & & \\
\hline 1 = fair/poor & $1=$ poor, $2=$ fair & 18.6 & \\
\hline $2=\operatorname{good}$ & $3=$ good & 34.6 & \\
\hline $3=$ very good/excellent & $4=$ very good, $5=$ excellent & 38.0 & \\
\hline SWFL & Number (range: 6-30) & 24.6 & 3.1 \\
\hline Frequency & Frequency of dinner in company & & \\
\hline 1 = daily & & 73.5 & \\
\hline $2=2-3$ times a week & & 9.5 & \\
\hline $3=$ weekends only & & 3.6 & \\
\hline 4 = occasionally & & 9.5 & \\
\hline $5=$ infrequently & & 3.9 & \\
\hline
\end{tabular}

Katz ADL: Index of Independence in Activities of Daily Living; QGoods: quantity of domestic household goods; SD: standard deviation; SHS: Subjective Happness Scale; SWES: satisfaction with economic situation; SWFL: Satisfaction with Food-related Life Scale.

* Monthly in US dollars at 2014 value;

** Per capita food expenditure of an individual in a household. 
Equation (1) represents the difference in happiness between the exclusive alternatives, where what really occurs is the result of the latent variable, i.e., $y_{i}$. The value of $y_{i}$ is determined by $y_{i}^{*}$ using the condition:

$$
\begin{aligned}
& y=0 \text { si } y_{i}^{*} \leq 0, \\
& y=1 \text { si } 0<y^{*}{ }_{i} \leq \gamma_{1}, \\
& \cdots \\
& y=J \text { si } \gamma_{j-1} \leq y^{*}{ }_{i} .
\end{aligned}
$$

The coefficient $\gamma$ is called "limit parameter". The conditional probabilities of each observed value of $y$ are obtained as:

$p(y=0)=\Lambda\left(\gamma_{1}-\beta^{\prime} x\right)$,

$p(y=1)=\Lambda\left(\gamma_{2}-\beta^{\prime} x\right)-\Lambda\left(\gamma_{1}-\beta^{\prime} x\right)$,

...

$p(y=(J-1))=1-\Lambda\left(\gamma_{J-1}-\beta^{\prime} x\right)$.

Where $\Lambda$ (.) represents the logistic distribution function. For $j$ categories of response there were $j$ equations which should be solved $(j=0,1,2$, ...J) and therefore there were $(J-1)$ "limit parameters". The joint estimation of $\beta$ was carried out by maximizing the log-likelihood function and was implemented with SPSS 15.0 for Windows in Spanish (SPSS Inc., Chicago, USA). The likelihood ratio was used to measure the goodness of fit of the models.

\section{Results}

Table 1 shows the descriptive statistics of the sample respondents. Of all participants $(\mathrm{N}=389)$ $37.4 \%$ were male and $61.8 \%$ were married or cohabiting (Table 1). Elderly participants ranged between 60 and 90 years old with an average age of 71.4 years $(\mathrm{SD}=6.5)$. The average number of children living at home was $0.5(\mathrm{SD}=0.9)$. The mean (SD) happiness score was 5.3 (1.0). The distribution was negatively skewed with a median of 5.3. 124 participants were classified as "not happy", 144 as "happy" and 121 as "very happy". The mean SWFL score of all the participants was 24.6 $(\mathrm{SD}=3.1)$. The Pearson correlation $(r)$ between SHS and SWFL was $0.23(\mathrm{p}<0.05)$. Of the entire sample, participants who had breakfast, lunch and dinner with their family on a daily basis predominated. Participants mainly have afternoon tea and dinner with their family on a daily basis. In terms of the number of days with health problems or limitations in the last 30 days, the average was 6.1 days $(S D=10.2)$. In terms of functionality (Katz ADL), the average was 17.3 days ( $\mathrm{SD}=$ 2.1). As for the number of days with limitations in common activities during the past 30 days, the average was 2.8 days $(\mathrm{SD}=7.2) .18 .6 \%$ of the participants perceive their health as fair/poor, $34.6 \%$ as good and $38 \%$ as very good/excellent.

Table 2 shows the mean of the monthly household food expenditure and the mean of the per capita monthly food expenditure by happiness and gender groups. Among the 389 participants who answered the expenditure question, the mean household food expenditure was 167.7 US dollars and the per capita household food expenditure was 73.9 US dollars. In this study we considered the household food expenditure as a proxy variable of household income for two reasons: first, because we do not have information on the household income for each respondent; second, because the lower income segments spend a higher percentage of their income on food consumption. However, no statistically significant differences were observed in the two measures of monthly food expenditure among the three defined happiness groups. No significant correlations between happiness and household food expenditure $(r=0.04, \mathrm{p}>0.1)$, happiness and per capita food expenditure $(r=$ $-0.01, \mathrm{p}>0.1)$ and happiness and socio-economic level $(r=-0.06, \mathrm{p}>0.1)$ were observed. Therefore, this first approach indicates that food expenditure does not explain the level of happiness of the rural elderly. The results in Table 2 also suggest no statistically significant differences in the three considered levels of happiness between the levels of food expenditure for women and men. These results do not appear to be consistent with those obtained by Hsieh 12 in that people who claim a higher level of happiness have a higher level of household income.

Prior to the results analysis, the correlation matrix of the explanatory variables was obtained, identifying different degrees of correlation, although, in general, almost all were weak. For example, no significant correlation between SWFL and Katz ADL ( $r=-0.03, \mathrm{p}>0.1)$, perceived health $(r=-0.08, \mathrm{p}>0.1)$ and common activities $(r=0.01, \mathrm{p}>0.1)$ was observed. Further, no significant correlation between SWES and healthrelated indicators was observed. Only two significant correlations were observed: between SWFL and SWES ( $r=0.22, \mathrm{p}>0.05)$ and between common activities and frequency of dinner in company $(r=0.18, \mathrm{p}>0.05)$. Therefore, one can conclude that there are no problems of collinearity between predictors.

The generated results of happiness of the ordered logit models are presented in Table 3. Model 1 shows the results of the relationship between SWES and happiness after controlling for age and age-squared. The signs of the coefficients of the generated logit model show directly the 
Table 2

Mean food expenditure (in 2014 US dollars) by happiness and gender.

\begin{tabular}{|c|c|c|c|c|}
\hline & Total sample & 1 = not happy & 2 = happy & $3=$ very happy \\
\hline Food household expenditure & 167.7 & 157.3 & 178.4 & 165.5 \\
\hline Male & 178.8 & 162.7 & 195.7 & 178.3 \\
\hline Female & 161.9 & 153.7 & 170.0 & 160.0 \\
\hline Levene's test * & 10.57 ** & $6.3^{* \star \star}$ & 5.1 *** & 0.87 \\
\hline$t$ test \# & 1.68 & 0.55 & 1.3 & 1.2 \\
\hline Per capita food expenditure & 73.9 & 76.0 & 75.0 & 70.4 \\
\hline Male & 75.7 & 76.0 & 78.2 & 72.4 \\
\hline Female & 72.3 & 76.1 & 71.0 & 70.0 \\
\hline Levene's test * & 6.56 ** & $4.1^{\star \star \star *}$ & $7.0 * \star \star \star$ & 0.01 \\
\hline$t$ test $\#$ & 0.64 & -0.01 & 0.9 & 0.2 \\
\hline
\end{tabular}

* Levene's test of variance homogeneity suggests that the population variances of the two groups (male and female) are not equal based on an $\mathrm{F}$ test, and then;

** Significance level: $p<0.01$;

$\star \star \star$ Significance level: $p<0.5$;

\# A $t$ test suggests that the mean values of the two groups are not statistically different based a test for mean equality.

Table 3

Estimated effects of satisfaction with economic situation and other variables on happiness.

\begin{tabular}{|c|c|c|c|}
\hline & $\begin{array}{c}\text { Model } 1 \\
\text { OR }(95 \% \mathrm{Cl})\end{array}$ & $\begin{array}{c}\text { Model } 2 \\
\text { OR }(95 \% \mathrm{Cl})\end{array}$ & $\begin{array}{c}\text { Model } 3 \\
\text { OR }(95 \% \mathrm{Cl})\end{array}$ \\
\hline Age & $2.07(1.19-3.61)$ & $1.95(1.10-3.45)$ & $2.33(1.28-4.24)$ \\
\hline Age-squared & $0.99(0.99-0.99)$ & $0.99(0.99-0.99)$ & $0.99(0.99-0.99)$ \\
\hline \multicolumn{4}{|l|}{ SWES } \\
\hline 1 = dissatisfied & $0.17(0.07-0.39)$ & $0.21(0.09-0.50)$ & $0.32(0.13-0.81)$ \\
\hline 2 = slightly satisfied & $0.11(0.05-0.24)$ & $0.13(0.06-0.29)$ & $0.18(0.08-0.44)$ \\
\hline $3=$ somewhat satisfied & $0.27(0.12-0.58)$ & $0.30(0.13-0.66)$ & $0.34(0.15-0.79)$ \\
\hline $4=$ extremely satisfied & 1.00 & 1.00 & 1.00 \\
\hline Katz ADL & & $1.14(1.02-1.28)$ & $1.13(1.01-1.26)$ \\
\hline Common activities (last 30 days) & & $0.97(0.94-1.00)$ & $0.96(0.93-0.99)$ \\
\hline \multicolumn{4}{|l|}{ Health } \\
\hline 1 = fair or poor & & $0.41(0.21-0.80)$ & $0.38(0.19-0.75)$ \\
\hline 2 = good & & $0.33(0.17-0.66)$ & $0.35(0.17-0.70)$ \\
\hline $3=$ very good/excellent & & 1.00 & 1.00 \\
\hline SWFL & & & $1.17(1.10-1.25)$ \\
\hline \multicolumn{4}{|l|}{ Frequency } \\
\hline 1 = daily & & & $7.28(2.11-25.1)$ \\
\hline $2=2-3$ times a week & & & $4.51(1.17-17.5)$ \\
\hline $3=$ weekends only & & & $4.81(0.89-25.9)$ \\
\hline $4=$ occasionally & & & $5.30(1.34-21.0)$ \\
\hline 5 = infrequently & & & 1.00 \\
\hline Likelihood ratio $\chi^{2}$ & 44.42 & 68.35 & 104.68 \\
\hline
\end{tabular}

95\% Cl: 95\% confidence interval; Katz ADL: Index of Independence in Activities of Daily Living; OR: odds ratio;

SWES: satisfation with economic situation; SWFL: Satisfaction with Food-related Life Scale.

Note: Dependent variable: happiness, observations: 389; Link function: logit. 
direction of the relationship of each independent variable with the happiness variable. The fit of Model 1 was significant at the level $\mathrm{p}<0.01$ for the likelihood ratio $\chi^{2}$ (44.42). The p-values show the individual significance of the coefficients. The results indicated that there was a significant positive relationship between SWES and happiness. This implies that people who are dissatisfied with their economic situation are less likely to be very happy compared to those who are extremely satisfied with their economic situation. The same reasoning applies for those slightly and somewhat satisfied with their economic situation. The positive coefficient of the variable age shows a higher probability of being very happy as the person ages, but this probability has the form of an inverted $U$ due to the statistical significance of the variable age-squared. Thus, there is a higher probability of being happy from the age of 73 years. However, at some point this probability should start to decrease. This means that happier older adults are more likely to be found among those most satisfied with their economic situation and those who are older (with a limit of 73 years). The fit of Model 2 was significant at the level $\mathrm{p}<0.01$ for the likelihood ratio $\chi^{2}$ (68.35), which suggests a better fit than Model 1. Model 2 shows the results of the relationship between SWES and happiness after controlling for age, age-squared and health-related variables. The results of Model 2 showed that, after controlling for health-related variables (including Katz ADL, common activities and perceived health), the significant positive relationship between SWES and happiness remained. Thus, happier older adults are more likely to be found among those more satisfied with their economic situation, older (this time with a limit of 69 years), and in better health. Model 3 shows the results of the relationship between SWES and happiness after controlling for age, age-squared, healthrelated variables and food-related variables. The results of Model 3 show that after the inclusion of the food-related variables (including SWFL and frequency of dinner in company), the significant positive relationship between SWES and happiness also remained. That is, happier older adults are more likely to be found among those more satisfied with their economic situation, older (this time with a limit of 71 years), in better health, more satisfied with their food and those who have their last meal of the day in company, hopefully as often as possible. The fit of Model 3 was significant at the level $\mathrm{p}<0.01$ for the likelihood ratio $\chi^{2}$ (104.68), which suggests a better fit than Models 1 and 2.

The value of the likelihood ratio $\chi^{2}$ increases when we compare Model 2 with Model $1\left(\Delta \chi^{2}=\right.$
23.93) and Model 3 with Model $2\left(\Delta \chi^{2}=36.33\right)$. These values show the gain of the model at each step when the variables of each respective step are included. That is, each step reflects changes in likelihood when new variables are added. As the change in likelihood is statistically significant at each step, additional included variables are maintained in the model.

\section{Discussion}

Using data from a questionnaire applied to 389 seniors in the Maule Region, Chile, information to answer the research questions was obtained. Regarding the first question, no significant differences between the expenditure on food consumption and the reported different levels of happiness were observed. Moreover, the expenditure on food consumption and socioeconomic level were not related to happiness in the elderly. This contrasts with some authors $12,14,13,15,20$ regarding the significant influence of household income on happiness. In this case the income or expenditure situation does not seem relevant. However, the satisfaction older adults obtain from food does, which may reflect the importance of food quality over quantity consumed. This result could also be influenced by the Comprehensive Positive Aging Policy for Chile and the "Choose Healthy Living" program, which invites the elderly to consume healthier foods as a way of aging in an active and healthy way. This means giving priority to quality over quantity of food and losing the relative importance of income or expense levels on food consumption.

The results of this study show that Chilean rural seniors in general declare themselves to be less happy than seniors in studies in Alabama 9 and Hong Kong ${ }^{2}$. One relevant factor to explain this discrepancy is the lower standard of living in Chile compared to the elderly in the United States and Hong Kong as considered in the studies by Angner et al. 9 and Nan et al. 2. According to International Monetary Fund (IMF) figures for 2014 , the average gross domestic product (GDP) per capita in these two countries is 2.8 times the GDP per capita in Chile, which imposes a hard budget constraint on high quality food consumption for elderly Chileans. The individual sociodemographic variables related with happiness are SWES and age. In line with the idea proposed by Shams 15, the results of this study indicate that age is an important predictor of happiness among the rural elderly, but unlike Selim ${ }^{14}$, who posed a negative relationship, our results show that age has a positive influence. Consumerism, as reported by Gray et al. 3, also has a strong 
influence on seniors' happiness in our model. This could be directly explained by the contribution to the subjective well-being of elderly of the service life associated with each of the goods available in the home, or because "real wealth" is part of the social capital of a person which contributes to happiness as suggested by Theurer \& Wister 16. Moreover, in line with what has already been reported by Gray et al. 3, the consumerism of our rural elderly, measured as the number of goods in the home (QGoods), could be included in the relative feeling of not being poor in comparison to one's neighbors $(67.3 \%$ reported having five or more goods in their home).

The hypothesis posed by Angner et al. 9 regarding the relationship between health and happiness is consistent with the results of this study. The impact of perceived health on happiness is consistent with that reported by several authors 19,14,13,9,15,10,25,34. Also, the rate of health limitations for common activities during the last 30 days may also help explain the happiness of elderly Chileans living in rural areas. Therefore, what matters is the general health perception, health limitations for common activities and daily functioning as a source of happiness. The consequence of this finding on public health policy for the elderly is that the emphasis should be on prevention, establishing policies to promote active and healthy aging and strengthening overall lifestyles that contribute to a healthier life for seniors.

The satisfaction with food-related life is an important predictor of happiness in Chilean rural older adults. In future studies, as suggested by Schnettler et al. ${ }^{39}$, this measure may serve as a useful dependent variable in analyzing how other objective indicators can have an impact on satisfaction with food-related life. Following Berenbaum 32, Macht et al. 33 and Yiengprugsawan et al. ${ }^{34}$, our results confirm that eating is an important source of happiness. However, it is also very important to eat in the company of others, which reaffirms the contribution to the hedonic well-being of food consumption.

The number of children living at home was not an explanatory variable in our model; the results point in the opposite direction of the literature 11,14,15. This result may be because in Chilean rural areas, where families live relatively close to one another, many families are related in differing degrees of kinship, and family groups also meet with a relatively high frequency to celebrate different life events such as weddings, christen- ings, birthdays and religious holidays. Therefore, seniors do not necessarily need to have children living at home to feel happier as they already frequently share moments with them. The level of education of rural older adults was not a significant variable in the model, which is consistent with the results of Patrick et al. 27 and Selim 14. However, our results differ from those reported by other authors $13,15,21,22$.

In contrast to the results of Selim 14, Portela \& Neira 13 and Yiengprugsawan et al. 20 , in this model marital status does not affect rural seniors' happiness, being consistent with the results of Patrick et al. 27. Gender was not significant, which is in line with what was reported by Patrick et al. 27, Gray et al. 3, Portela \& Neira 13 and Yiengprugsawan et al. 20, but differs from what was reported by Selim 14 and Shams 15, who concluded that gender is an important predictor of happiness.

These results for Chile are in agreement with the implementation of public policies to improve the access of health care for rural seniors, particularly those on a lower socioeconomic level. However, greater efforts are required when it comes to access to health care, for example incorporating all the pathologies linked to age-related physical health in public health programs and investing more state funding for the often expensive treatment associated with these diseases. As for functional activities, for rural older adults with severe functional impairment or moderate functional impairment, the probability of being very happy decreases compared to those who are independent. Our results are consistent with the growing social and personal relationships as a way for the elderly to remain integrated in society, thus avoiding feeling isolated and alone. Therefore, together with strengthening family relationships it may be useful to strengthen social assets such as seniors' centers, cultural centers and recreational spaces that facilitate the integration of the elderly into the community. Finally, following Sheldon \& Lyubomirsky 6 , for society as a whole it seems to be very profitable to promote happiness due to its implications on social life and public health. Furthermore, our results confirm the importance of factors associated with health and food satisfaction as predictors of happiness even more than factors associated with money, such as food expenditure and socioeconomic status. Therefore, in the case of Chilean rural elderly, the saying "between health and money, health first!" seems to be true. 


\section{Contributors}

G. Lobos contributed to the study design, data collection, statistical analysis, data interpretation, writing, critical review of the intellectual content of the manuscript, and approval of the final version for publication. M. C. Lapo and B. Schnettler contributed to the study design, data analysis, writing and review of the manuscript. All authors read and approved the manuscript.

\section{Acknowledgments}

This work was supported by the Interdisciplinary Excellence Research Program on Healthy Ageing (PIEI-ES), Universidad de Talca, Chile.

\section{References}

1. Frey BS, Stutzer A. What can economists learn from happiness research? J Econ Lit 2002; 40: 402-35.

2. Nan H, Ni MY, Lee PH, Tam WWS, Lam TH, Leung GM, et al. Psychometric evaluation of the Chinese version of the Subjective Happiness Scale: evidence from the Hong Kong FAMILY cohort. Int J Behav Med 2014; 21:646-52.

3. Gray RS, Rukumnuaykit P, Kittisuksathit S, Thongthai V. Inner happiness among Thai elderly. J Cross Cult Gerontol 2008; 23:211-24.

4. Alexandrova A. Subjective well-being and Kahneman's objective happiness. J Happiness Stud 2005; 6:301-24.

5. Max H, Markus H. How social relations and structures can produce happiness and unhappiness: an international comparative analysis. Soc Indic Res 2006; 75:169-216.

6. Sheldon KM, Lyubomirsky S. Is it possible to become happier? (And, if so, how?). Soc Personal Psychol Compass 2007; 1:129-45.
7. Lyubomirsky S, Lepper HS. A measure of subjective happiness: preliminary reliability and construct validation. Soc Indic Res 1999; 46:137-55.

8. Angner E, Ray M, Saag K, Allison J. Health and happiness among older adults: a community-based study. J Health Psychol 2009; 14:503-12.

9. Angner E, Ghandhi J, Purvis KW, Amante D, Allison J. Daily functioning, health status, and happiness in older adults. J Happiness Stud 2013; 14:1563-74.

10. Lobos G, Grunert KG, Bustamante M, Schnettler B. With health and good food, great life! Gender differences and happiness in Chilean rural older adults. Soc Indic Res 2015; doi: 10.1007/s11205015-0971-0.

11. Chyi H, Mao S. The determinants of happiness of China's elderly population. J Happiness Stud 2012; 13:167-85.

12. Hsieh CM. Money and happiness: does age make a difference? Ageing Soc 2011; 31:1289-306 
13. Portela M, Neira I. Capital social y bienestar subjetivo. Un análisis para España considerando sus regiones. Investigaciones Regionales 2012; 23:5-27.

14. Selim S. Life satisfaction and happiness in Turkey. Soc Indic Res 2008; 88:531-62.

15. Shams K. Determinants of subjective well-being and poverty in rural Pakistan: a micro-level study. Soc Indic Res 2014; 119:1755-73.

16. Theurer K, Wister A. Altruistic behaviour and social capitals predictors of well-being among older Canadians. Ageing Soc 2010; 30:157-81.

17. Veenhoven R. Effects of happiness on physical health and the consequences for preventive health care. J Happiness Stud 2008; 9:449-69.

18. Vera-Villarroel P, Celis-Atenas K, Córdova-Rubio N. Evaluación de la felicidad: análisis psicométrico de la escala de felicidad subjetiva en población chilena. Ter Psicol 2011; 29:127-33.

19. Lyubomirsky S, King L, Diener E. The benefits of frequent positive affect: does happiness lead to success? Psychol Bull 2005; 131:803-55.

20. Yiengprugsawan V, Somboonsook B, Seubsman S, Sleigh AC. Happiness, mental health, and socio-demographic associations among a national cohort of Thai adults. J Happiness Stud 2012; 13:1019-29.

21. Mahadea D, Ramroop S. Influences on happiness and subjective well-being of entrepreneurs and labour: Kwazulu-Natal case study. S Afr J Econ 2015; 245-59.

22. Gerstenbluth M, Rossi M, Triunfo P. Felicidad y salud: una aproximación al bienestar en el Río de la Plata. Estudios de Econonomía 2008; 35:6578.

23. Moyano E, Ramos N. Bienestar subjetivo: midiendo satisfacción vital, felicidad y salud en población chilena de la Región Maule. Universum 2007; 22:177-93.

24. Yunong H. Family relations and life satisfaction of older people: a comparative study between two different hukous in China. Ageing Soc 2012; 32: 19-40.

25. Lima MG, Barros MBA, Alves MCGP. Sentimento de felicidade em idosos: uma abordagem epidemiológica, ISA-Camp 2008. Cad Saúde Pública 2012; 28:2280-92.

26. Ferrer-I-Carbonell A, Frijters P. How important is methodology for the estimates of the determinants of happiness? Econ J (London) 2004; 114:641-59.

27. Patrick JH, Cottrell LE, Barnes KA. Gender, emotional support, and well-being among the rural elderly. Sex Roles 2001; 45:15-29.

28. Bisogni CA, Connors M, Devine CM, Sobal J. Who we are and how we eat: a qualitative study of identities in food choice. J Nutr Educ Behav 2002; 34:128-39.

29. Hausman A. Hedonistic rationality: the duality of food consumption. Adv Consum Res 2005; 32: 404-5.

30. Kniazeva K, Venkatesh A. Food for thought: a study of food consumption in postmodern US culture. Journal of Consumer Behavior 2007; 6:419-35.
31. Hargreaves M, Schlundt D, Buchowski M. Contextual factors influencing the eating behaviours of African American women: a focus group investigation. Ethn Health 2002; 7:133-47.

32. Berenbaum H. Varieties of joy-related activities and feelings. Cogn Emot 2002; 16:473-94.

33. Macht M, Meininger J, Roth J. The pleasures of eating: a qualitative analysis. J Happiness Stud 2005; 6:137-60.

34. Yiengprugsawan V, Banwell C, Takeda W, Dixon J, Seubsman S, Sleigh AC. Health, happiness and eating together: what can a large Thai cohort study tell us? Glob J Health Sci 2015; 7:270-7.

35. Schnettler B, Miranda H, Sepúlveda J, Denegri M, Mora M, Lobos G. Satisfacción con la alimentación en personas Mapuche en la Región Metropolitana de Santiago, Chile. Arch Latinoam Nutr 2011; 61:172-82.

36. Veenhoven R. Why social policy needs subjective indicators. Soc Indic Res 2002; 58:33-45.

37. Vera-Villarroel P, Celis-Atenas K, Pavez P, Lillo S, Bello F, Díaz N, et al. Money, age and happiness: association of subjective wellbeing with sociodemographic variables. Rev Latinoam Psicol 2012; 44:155-63.

38. Grunert K, Dean D, Raats M, Nielsen N, Lumbers M. A measure of satisfaction with food-related life. Appetite 2007; 49:486-93.

39. Schnettler B, Miranda H, Sepúlveda J, Denegri M, Mora M, Lobos G, et al. Psychometric properties of the satisfaction with food-related life scale: application in southern Chile. J Nutr Educ Behav 2013; 45:443-9.

40. Hennessy C, Moriarty D, Zack M, Scherr P, Brackbill R. Measuring health-related quality of life for public health surveillance. Public Health Rep 1994; 109:665-72.

41. Toet J, Raat H, van Ameijden EJ. Validation of the Dutch version of the CDC core healthy days measures in a community sample. Qual Life Res 2006; 15:179-84.

42. Schnettler B, Denegri M, Miranda H, Sepúlveda J, Orellana L, Paiva G, et al. Eating habits and subjective well-being among university students in southern Chile. Nutr Hosp 2013; 28:2221-8.

43. Katz S, Ford AB, Moskowitz RW, Jackson BA, Jaffe MW. Studies of illness in the aged. The index of ADL: a standardized measure of biological and psychosocial function. JAMA 1963; 185:914-9.

44. Adimark. Mapa socioeconómico de Chile, 2004. http:// www.adimark.cl (accessed on 07/Jan/2014).

45. Organization for Economic Co-operation and Development. Growing unequal? Income distribution and poverty in OECD countries. http://www. oecd.org/els/social/inequality (accessed on 03/ $\mathrm{Jul} / 2013$ )

46. Greene WH. Análisis econométrico. 3ạ Ed. Madrid: Prentice-Hall; 1999. 


\section{Resumen}

Investigamos la relación entre felicidad, el contexto sociodemográfico individual y las variables de salud y alimentación. Se entrevistaron a 389 ancianos con edades entre 60 y 90 años viviendo en áreas rurales, en la Región de Maule, Chile Central. Fue utilizada la escala de felicidad subjetiva de Lyubomirsky \& Lepper (1999). Se estimaron modelos de regresión logística ordinal. La variable dependiente discreta es el nivel de felicidad. Descubrimos que las siguientes variables están significativamente relacionadas con la felicidad: (1) Variables sociodemográficas individuales tales como edad y satisfacción con la situación económica; (2) Variables de salud, tales como la independencia en las actividades de la vida diaria, actividades comunes y salud percibida; y (3) Variables en la alimentación como la satisfacción con la vida relacionada con las comidas y la frecuencia con la que los adultos mayores cenan con otras personas. Una importancia significante de este estudio sugiere que se hagan esfuerzos más eficientes en la salud para el consumo saludable de los ancianos que viven en áreas rurales.

Felicidad; Medio Rural; Conductas Saludables; Anciano

\section{Resumo}

Nós investigamos a relação entre felicidade e contexto sociodemográfico individual e as variáveis de saúde e alimentação. Foram entrevistados 389 idosos com idades entre 60 e 90 anos, vivendo em áreas rurais, na Região de Maule, Chile Central. Foi utilizada a escala de felicidade subjetiva de Lyubomirsky \& Lepper (1999). Foram estimados modelos de regressão logística ordinal. A variável dependente discreta é o nível de felicidade. Descobrimos que as seguintes variáveis são significativamente relacionadas com a felicidade: (1) variáveis sociodemográficas individuais, tais como idade e satisfação com a situação econômica; (2) variáveis de saúde, tais como a independência nas atividades da vida diária, atividades comuns e saúde percebida; e (3) variáveis na alimentação, como a satisfação com a vida relacionada com as comidas e a frequência com que os adultos maiores jantam com outras pessoas. Uma importância significante deste estudo é sugerir para que se façam esforços mais eficientes na saúde para o consumo saudável dos idosos que vivem em áreas rurais.

Felicidade; Zona Rural; Comportamentos Saudáveis; Idoso
Submitted on 02/Mar/2015

Final version resubmitted on 28/Sep/2015

Approved on 15/Oct/2015 